\title{
Discussion on Socialist Core Values in Promoting National Cultural Soft Power
}

\author{
Donghai Jin \\ School of Marxism \\ Wuhan University of Technology \\ Wuhai, China 430072
}

\begin{abstract}
The 18th CPC National Congress Report of 2012 put forward to establish socialist core value system from three levels:"the first is prosperity, democracy, civilization and harmony at national level; the second is liberty, equality, justice and rule of law at social level; the third is patriotism, devotion, honesty and kindness at citizen level."[1] In order to promote national cultural soft power, the inheritance of Chinese excellent traditional culture shall be combined with current moral culture construction under the guidance of socialist core value system, and at the same time, it shall be connected with localization of Marxism in China organically.
\end{abstract}

Keywords-socialist core values; promote; national cultural soft power

\section{INTRODUCTION}

The 18th CPC national congress report put forward to establish socialist core value system from three levels:"the first is prosperity, democracy, civilization and harmony at national level; the second is liberty, equality, justice and rule of law at social level; the third is patriotism, devotion, honesty and kindness at citizen level."[1] In order to promote national cultural soft power, all the screening and inheritance of Chinese excellent traditional culture, the current rule-of-law concept education as well as the localization of Marxism in China shall be combined with the construction of socialist core values organically under the guidance of socialist core value system.

\section{Socialist CORE VALUES’ Role IN PROMOTING NATIONAL CUlTuRAL SOFT POWER}

The socialist core value system as proposed in the 18th National Congress is the concept of value reflecting socialist basic needs comprehensively, and at the same time, the establishment of harmonious social relations and value pursuit, the systematic value idea formed and developed in the constant socialism reform and opening up, and the value idea to guide China to construct the powerful socialist country. Construction of the socialist core value system with Chinese characteristics is a very important content emphasized in the 18th National Congress Report, and a great task proposed after the CPC has summarized the historical experience profoundly and analyzed the current situation scientifically. The three aspects basic contents of socialist core values interact and connect with each other in a progressive manner, and they are unified organically.

Donghai Jin, Ph.D. candidate, School of Marxism, Wuhan University of Technology.
They run through all aspects of improving the national cultural soft power, being the value concept generally accepted consciously followed by all social members. The socialist core values are the spiritual pillar, intrinsic motivation and the soul of the socialist system in our country, playing a core role among all the values, and also playing the leading role in cultural construction. "National culture system construction plays a very important role in promoting the national core competitive soft power, while the cultural construction is conducted under the guidance of socialist core values, so the system of socialist core values is the basis and premise for promoting national cultural soft power and the necessary condition for the formation and development of national cultural soft power." [2] National cultural soft power is the further extension of socialist core values, and the inevitable product of the social development to a certain period and the external manifestation of socialist core values. Therefore, the enhancing of national cultural soft power is the systematic construction and completion of socialist core values.

\section{ANALYSIS OF CONCEPT OF SOCIALIST CORE VALUES}

The 18th CPC National Congress put forward the basic content of socialist core values of 24 Chinese characters, "the value target at national level, the value orientation at social level, and the value criterion at the level of citizens are reflected comprehensively and systematically for the first time, especially the unity of national, social and citizen levels is realized."[3]

From the national level, it is prosperity, democracy, civilization and harmony. The modernization and development of our country is an overall concept, a complete social phenomenon, as well as the multidimensional, integrated and complicated system engineering. It integrates economic construction, political construction, social construction, cultural construction and ecological civilization construction with overall coordination, mutual promotion and all-round development.

From the social level, it is freedom, equality, justice and rule of law. Promoting social fairness and justice and improve people's welfare is the starting and ending point of the reform, and the greatest common divisor of the reform we are talking today. It refers to benefit all the people using the fruits of reform, and share the achievements of reform with all the people, to truly achieve that every child can go to school, 
everyone can obtain benefits from their work, everyone has a roof over the head, every sick is treated and the elderly are taken care of, which reflects a kind of social fairness and justice. At the same time, the Decision of the third plenary session of the 18th central committee of CPC lays special emphasis on rule of law, and there is a special clause in the Decision about building the law-governed China. General Secretary $\mathrm{Xi}$ jinping has mentioned the legal thinking many times in his speeches, advocating solving problems using legal methods. He said: "anyone major reform must has a legal basis. We shall make people feel the judicial fairness and justice, the power of the rule of law and the power of governing the country according to law through each specific judicial cases, to construct the law-governed China." This refers to advocating fairness and justice and governing China according to law. Again, the nearby enrollment policy and the reeducation abolition all reflect a spirit of freedom and equality. Therefore, the value of freedom, equality, and justice, rule of law in the reform and development of contemporary China is more prominent.

As for the citizen level, it is patriotism, dedication, honesty and kindness, which are also particularly important. Especially the problem of honesty is a great subject in front of us, and also a serious challenge. We shall strengthen moral construction and honesty construction, to improve the credibility of the society.

\section{SignifiCANCE OF CUlTIVATING AND PROMOTING SOCIALIST CORE VALUES}

The system of socialist core values as proposed in the 18th National Congress of the CPC matches China's status in the primary stage of socialism very well, corresponds to the socialist market economy development theory with Chinese characteristics as carried out currently, is consistent with the goal of building a well-off society, and connects to further absorbing the achievements of Chinese excellent traditional culture, that is to say "the systematic socialist core values reflect the basic characteristics and fundamental nature of national core value system as well as reflects the specific practice requirements and rich spiritual connotation of national core values system. It not only refines the system of socialist core values highly, but also makes a centralized summarization of the socialist core value system." [4] The system of socialist core values is standard of value to be followed for building a prosperous, democratic, civilized and harmonious country.

\section{A. Five Senses of Cultivating and Promoting the Socialist Core Values:}

- the cultivating and promoting of socialist core values can enhance national cultural soft power. Standing on the general direction, China need learn to adapt to the domestic and international changes. The international situation is undergoing profound changes unceasingly, while the Chinese society is also in the key period of development, transformation and adjustment, and is undergoing a reform, development and opening up process that has never been experienced over more than two thousand years. All kinds of values, beliefs and social ideological trend, such as universal values, western Marxism, traditional Chinese Confucianism, and Legalism and so on emerge constantly. At the same time, along with the accelerating development of Chinese reform, western Catholicism and Christianity are carried out rapidly in mainland China, especially the urban teachers, doctors and rural leftover personnel are the groups to be developed with emphasis by the western churches. Facing the problems of global cultural exchange and collision of values, the ideology diversity generated in the process of reform and opening up, the cultural concept need to be carried out for the construction of socialist country with Chinese characteristics, the orientation support need to make Marxism further localized in China and the screening need for absorption of traditional culture, the core value system is needed to be established urgently, and the socialist core value system is also needed to be cultivated and promoted, especially to expand the influence of the concept of national core values, to enhance national cultural soft power eventually.

- the construction of socialist core values system can promote national governance system perfection and the enhancement of national governance ability. Cultivate and promote the national core value system, integrate social consciousness effectively and form a unified value system of socialist country, will play a very important role in not only improving national governance system, but also in the enhancement of country governance ability. "In order to realize the dream of socialist power, we need to further deepen political/economic and cultural system reform, and to further develop and perfect socialist market economy system with Chinese characteristics, and to further promote the construction of the system of law-governed country. In order to achieve this, the problems about values commonly recognized by all citizens shall be resolved first of all, and construct the ideological system that can fully reflect the Chinese characteristics, Chinese national characteristics, and at the same time, can organically connect with Chinese traditional culture and localization of Marxism in China." [5] Upon the values are established, the system of socialist core values shall be cultivated and promoted in the whole society vigorously, to make the socialist core values be rooted in people's heart, so as to improve all citizens' overall understanding and systematic cognitive ability of the socialist core values. Carry out the national education taking full use of core value system from the national, social and citizen levels, to make the system of socialist core values get the absolute right of speech and absolute leadership, so as to promote the further perfection of national governance system and further improvement of the national governance ability, under the legal environment which can reflect the socialist core values.

- the systematic construction of socialist core values can enhance national cohesion and centripetal force. Today's society develops too fast, and contemporary China is in a quickly changing world. The changing 
pace of the whole world is faster than before, resulting in fast spread of new cultural values. Different ideology, culture and values in the world of world clash and blend each other constantly. Different values integrate constantly in the collision, and in turn, they clash each in the integration. As a result, the cognition toward values of different group tends to be changeable and diversified. Now, the world is undergoing globalization, digitalization, information and networking with cloud computing and big data. The values of young people are presenting independence, difference, diversity and variability. "In today's society, we face the diversified demands for interests, social cognition, academic point of view and value judgment. Each individual' and each group's perception of the same thing may generate different points of view, which requires the ideology guidance, spiritual flag and cultural orientation." [6] The socialist core values carried out by the state is to undertake the task and mission of ideology guidance and spiritual guide, so as to gather the national basic social consensus and lead the social development direction, to achieve the ultimate goal of promoting national cultural soft power.

- the systematic construction of socialist core values can provide strong driving force for deepening reform comprehensively. The decision on deepening reform comprehensively passed on the Third Plenary Session of the 18th CPC National Congress emphasizes peoplecentered work orientation, namely people supremacy. At the same time, emphasize equity and justice with special emphasis, taking it as the starting and finishing point of reform. At the same time, stress rule of law in China, legal thinking and method of rule by law with special emphasis, to realize the unity of the lawgoverned country, law-governed government and lawgoverned society. People supremacy, equity and justice and law-governed China will greatly inspire people's positive energy for the reform, and infuse new vitality into reform, so as to obtain more widely recognition from the society, as well as to lay a solid social foundation for the promotion of socialist core values. Because only by promoting the construction of socialist core value system systematically, can the reform's achievements be reflected truly, the achievements of reform and development be shared by all the citizens and the concept of governing for the people be truly reflected. Only in this way can the socialist value system become the power driving reform.

- the socialist core values are the value support of social harmony. The 30 years' reform and opening-up is a critical period and the opportunity period for development, of course it is also a period with prominent contradictions. Facing the problems of how to deal with the conflicts between national interests and personal interests, social interests and personal interests as well as social interests and national interests, how to stimulate vitality of each member of the society, how to eliminate the contradictions between various social aspects, how to safeguard social fairness and justice, how to promote the harmonious and stable development of the society as well as how to carry out well-off society construction, the state shall grasp the country's future development orientation systematically and establish the socialist core value system completely, to eliminate the contradictions between various social aspects, in order to provide a support of value system for building a harmonious society.

\section{B. Paths for Improving National Cultural Soft Power under the Guidance of Socialist Core Values}

1) Cultivate and promote socialist core values based on the traditional Chinese excellent culture: Regard the cultivating and promoting socialist core value system construction as the basic engineering of upgrading national cultural soft power based on the traditional Chinese excellent culture. The cooperative development of cultivating and promoting socialist core values and the inheritance of traditional excellent cultural traditions can be carried out from the following three aspects. The first is to establish the core position of socialist core values. The values of a country with strong core values must have its intrinsic root, at the same time, they must be blended together with the essence of traditional culture. As a result, blind abandon of traditional culture means to cut off the source of its own spirit lifeblood. The historical lessons resulted by the Great Cultural Revolution has caused profound negative impact on today's cultural system incompletion. "Today, the construction of cultural system is to absorb the essence of the extensive and profound traditional Chinese culture and abandon the dross under the guidance of socialist core values. Urban and rural cultural fusion make the new cultural value system stand firm in the new era." The Chinese nation's deepest spiritual pursuit is contained in Chinese excellent culture, which represents the Chinese nation's unique spiritual identity; thanks to the rich nourishment provided for the country and nation's development by excellent traditional Chinese culture, the Chinese nation can live and grow continuously for more than two thousand years, and develop and grow stronger; Second, the value concept matches core values shall be excavated indepth from the excellent traditional Chinese culture under the guidance of socialist core values. For example, the concept of "kindness, people-oriented, integrity, justice, peace and great harmony" of traditional Chinese culture, "[7] meets the cultural orientation of socialist core values, and matches the current era development, which not only has rich connotation, but also has use value within this era. Third, we should treat and learn the traditional culture correctly. We shall learn to inherit the excellent part of traditional culture under the guidance of socialist core value system, and learn to absorb the essence of the traditional part, so as to make further innovation, raise the essence of traditional culture to a higher level and integrate it into the culture system of socialist core values. The problems of traditional culture's inheritance and development, development and innovation, as well as 
innovation and localization shall be handled well for the cultivation and development of socialist core value system.

2) Conduct the creative transformation and innovative development of traditional culture very well under the guidance of socialist core values: In order to conduct creative transformation and innovative development of traditional Chinese culture very well, the following three points shall be completed. First, handle the relationship between modern culture and traditional culture properly. "Traditional culture with the history of thousands of years is tradition, but some of its content is beyond the tradition, beyond the age, having the nature of modernity. So we shall combine tradition and modern, to make the traditional culture adapt to the modern society and coordinate with modern civilization."[8] Second, handle the relationship between inheritance and innovation properly. Traditional culture shall be inherited with priority, and inheritance shall be the premise and foundation. At the same time, innovation shall be made, as innovation is the orientation and life." "Culture is a nation's blood, the spiritual home of the people. A nation's cultural identity is a mark of a nation in the process of globalization. As for inheritance, it is our spiritual home, our root, our soul and our blood."[9] But, in the 21 st century, the human society is an era of innovation. Formulate the national policy systematically to arouse the vitality of whole society culture innovation. Give play to the whole nation for cultural innovation, to inheritance the essence of profound traditional Chinese culture, make efforts to create cultural works accord with the needs at national level, social level and citizens level. The third is the content and form of culture. Culture should be the unity of content and form. Nationality is a kind of form, but it is not only just the form, but also the content. Nationality shall not only be embodied in the form, but also should be reflected in the content. Only national culture that can be manifested not only in the form, but also in content, can be the culture with influence and vitality. As for the identity and inheritance of traditional culture, it reflects the unity of the form of nationality and the content of nationality.

3) Realize localization of Marxism in China under the guidance of socialist core values: Socialist core values are the soul and guidance of our country and nation. Marxism is the guiding ideology of the communist party, and the excellent traditional Chinese culture is our foundation to stand firm in the development and change of world culture. Therefore, we shall explore in-depth the contemporary value of the excellent traditional Chinese culture and further promote the localization of Marxism in China under the guidance of the system of socialist core values as proposed in the 18th National Congress. The ultimate goal of Marxism is the great harmony, which is consistent with China's Confucian target. At the same time, Marxism pursues fairness and justice, which is also consistent with socialist core values' goal. In the future, we shall the three aspects, to promote the combination of Marxism with excellent traditional Chinese culture in the process of its localization in China, to form China's own cultural value content and system.

4) Integrate the cultivation and practice of socialist core values into the whole process of national education: The Cultivation and practice of socialist core values must integrate the thought of socialist core values into the national systematic cultural education. Involve the promotion and implementation of socialist core values into the national education overall plan. At the same time, implement it systematically in various fields such as basic education, higher education, vocational and technical education, and implement it into each segment of teaching and management of the education system, thus to cover all school teachers, students and education administrators and form the coordinated education mechanism of social education, classroom teaching and campus culture construction. The excellent traditional Chinese culture education absorbs and integrates as well as be promoted unceasingly, to connect the excellent traditional Chinese culture with socialist core values organically. Improve the integration of school education, family education and social education constantly, and constantly guide the mutual cooperation among students' parents, various social aspects and school education, to promote the harmony of family atmosphere, establish a good social atmosphere, and further consolidate the school education achievements, so as to form the resultant force of society, school and family, to facilitate the cultivation of socialist core value system. And integrate the socialist core values into the national education system, to cultivate a group faculty with high quality, skilled profession and noble ethics, guide the teachers set up the sense of honor and responsibility of being others' teachers, as well as guide and lead the students to practice the socialist core values.

5) Implement the cultivation and practice of socialist core values into economic reform and social governance: The 18th CPC National Congress determines to take socialist core values as the guidance for both economic development and social governance. The aspects of setting the economic development target and development strategy planning, issuing national policies and formulating major reform measures, etc., should be carried out under the guidance of socialist core values, and shall be considered systematically from the state, society and individual, and shall pay attention to the organic unity of economic behavior and value orientation, the organic unity of economic development and culture construction, as well as the organic unity of economic benefit and social benefit. In addition, in the process of economic development and social governance, we shall establish and improve the state policy-making mechanism, establish and execute the systematic evaluation mechanism of policy from the aspects of state, society and individual. At the same time, the emergency correction mechanism shall also be formulated in the course of policy and system execution, so as to prevent the phenomenon of unable to integrate the 
formulation and execution of policies and the socialist core values.

Govern the country by law is an important guarantee to promote socialist core values. Government departments at all levels shall continuously carry out the rule of law and legal administration under the guidance of socialist core values, at the same time, implement it into various segments of popularizing law, legislation, law enforcement and govern by law, to promote the citizens' consciousness of cultivation and practicing the socialist core values using the concept of governing the country by law. Formulate relevant requirements of ruling by law into the detailed regulations and interpretation of law, so as to give full play to the role of guidance, regulation and guarantee of law, establish the legal environment for cultivating and practicing the socialist core values. "In terms of social governance, list the implementation of socialist core values as the important content, integrate it into the legal system construction and national governance, to form a scientific, perfect and effective conflict mediation mechanism, interest coordination mechanism, demand expression mechanism, as well as rights and interests safeguard mechanism, so as to maximize social harmony."[10] Moreover, in order to promote socialist core values in rural areas, we also need to constantly improve village regulations, students' code of conduct, industry norms and ethical standards, and constantly improve the improvement and implementation of legal system. Reflect the socialist core values in various links of daily management in the countryside society, to make each citizen know which can be done, and which cannot.

As the value system, culture can only be rooted in social life, rather than exist in the teachings of Marx or that of the Confucian system. Only the belief generally accepted by all people from urban and rural society and practically guide the public's daily behavior can become the values of the society. In addition, the systematic culture system can only be established based on the corresponding system construction. The problem of socialist core values is an important theoretical and practice problem at present. We shall further enhance the citizens' cultural quality, enhance our country's cultural soft power, and promote the construction of socialism with Chinese characteristics, to achieve the Chinese dream of great rejuvenation of Chinese nation through cultivating and practicing the socialist core values.

\section{REFERENCES}

[1] The 18th CPC National Congress Report, People's Publishing House, 2012-11.

[2] Guo Jianning. Cultural Sources of Socialist Core Values and Its Practical Significance, Study of Mao Zedong, 2015-03-08 25-28.

[3] Zhang Ji. Interpretation of Socialist Core Value System, Songzhou Social Science Review, 2014-06-15.

[4] Wang Wenqing. Discussion on Practicing Socialist Core ValuesAnalysis of Development Form and Understanding of Socialist Core Values - Gansu Theory Seminar on Cultivating and Practicing Socialist Core Values-2015-01-12.

[5] Same as the above.

[6] Yu Jinxi. Discussion on the Leading Role of Socialist Core Values in Cultural Construction - Theory Horizon- 2013-04-10.
[7] Wang Kequn, Shi Shushuo. Learning of the Important Statements Made by General Secretary Xi jinping on Socialist Core Values, Qianjin. 2014-10-08.

[8] Adhering to "Three Advocates" to Actively Cultivate and Practice Socialist Core Values, The New Long March (Party Construction Version) -2014-03-05.

[9] Same as the above.

[10] Guo Jianhui. Cultivate and Practice Socialist Core Values VigorouslyTheory Review-2014-09-20. 